Archives of Agriculture and Environmental Science

\title{
Effect of plant spacing and integrated nutrient management on the yield performance of Binadhan-14
}

\section{Roshida Yasmin, Swapan Kumar Paul* (iD , Shabuj Chandra Paul and Muhammad Salim}

Department of Agronomy, Bangladesh Agricultural University, Mymensingh-2202, BANGLADESH

${ }^{*}$ Corresponding author's E-mail: skpaul@bau.edu.bd

\section{ARTICLE HISTORY}

Received: 22 November 2018

Accepted: 02 December 2018

\section{Keywords}

Aman season

Binadhan-14

Nutrient management

Plant spacing

Recommended dose

Yield

\begin{abstract}
An experiment was conducted at the Agronomy Field Laboratory, Bangladesh Agricultural University, Mymensingh during the period from June to December 2014 with a view to finding out the effect of plant spacing and integrated nutrient management on the yield of Binadhan14. The experiment consisted of three spacing viz., $25 \mathrm{~cm} \times 15 \mathrm{~cm}, 20 \mathrm{~cm} \times 20 \mathrm{~cm}$ and $20 \mathrm{~cm} \times$ $15 \mathrm{~cm}$ and seven nutrient management viz., recommended dose of inorganic fertilizer @ 180150-70-65-8 kg ha-1 of Urea-TSP-MoP-Gypsum-ZnSO ${ }_{4}$ respectively, cowdung @ $10 \mathrm{t} \mathrm{ha}^{-1}$, poultry manure @ $5 \mathrm{t} \mathrm{ha}^{-1}, 50 \%$ recommended dose of inorganic fertilizer + cowdung @ $5 \mathrm{t} \mathrm{ha}^{-1}$, $50 \%$ recommended dose of inorganic fertilizer + poultry manure @ $2.5 \mathrm{t} \mathrm{ha}^{-1}, 50 \%$ recommended dose of inorganic fertilizer + cowdung @ $10 \mathrm{t} \mathrm{ha}^{-1}, 50 \%$ recommended dose of inorganic fertilizer + poultry manure @ $5 \mathrm{t} \mathrm{ha}^{-1}$. The experiment was laid out in a randomized complete block design with three replications. Crop characters, yield components and yield of Binadhan14 were significantly influenced by spacing, integrated nutrient management and their interaction. The highest number of effective tillers hill ${ }^{-1}(6.81), 1000$-grain weight (22.67 g) and grain yield (4.78 $\mathrm{t} \mathrm{ha}^{-1}$ ) were recorded at the spacing $20 \mathrm{~cm} \times 15 \mathrm{~cm}$ while in case of integrated nutrient management, the highest number of grains panicle ${ }^{-1}(64.47)$ was found with $50 \%$ recommended dose of inorganic fertilizer + cowdung @5 $\mathrm{t} \mathrm{ha}^{-1}$, on the other hand, 1000- grain weight (22.91g), and grain yield (5.02 $\left.\mathrm{t} \mathrm{ha}^{-1}\right)$ were found with $50 \%$ recommended dose of inorganic fertilizer + poultry manure @ $5 \mathrm{t} \mathrm{ha}^{-1}$ while the lowest values from poultry manure @ $5 \mathrm{t} \mathrm{ha}^{-1}$. The highest grain $\left(5.53 \mathrm{t} \mathrm{ha}^{-1}\right)$ and straw $\left(6.23 \mathrm{t} \mathrm{ha}^{-1}\right)$ yields were found at the interaction of $20 \mathrm{~cm} \times 15 \mathrm{~cm}$ spacing fertilized with $50 \%$ recommended dose of inorganic fertilizer + poultry manure @ $5 \mathrm{t} \mathrm{ha}^{-1}$. It can be concluded that short duration Binadhan-14 can be transplanted at the $20 \mathrm{~cm} \times 15 \mathrm{~cm}$ spacing fertilized with $50 \%$ recommended dose of inorganic fertilizer + poultry manure @ $\mathrm{t} \mathrm{ha}^{-1}$ to obtain maximum grain yield.
\end{abstract}

(C)2018 Agriculture and Environmental Science Academy

Citation of this article: Roshida, Y., Paul, S.K., Paul, S.C. and Salim, M. (2018). Effect of plant spacing and integrated nutrient management on the yield performance of Binadhan-14. Archives of Agriculture and Environmental Science, 3(4): 354-359, https://dx.doi.org/10.26832/24566632.2018.030404

\section{INTRODUCTION}

Rice (Oryza sativa L.) is the most extensively cultivated crop in Bangladesh and the staple food for her people. There are three distinct growing season of rice namely Aus, Aman and Boro in Bangladesh. The production of rice in Aus, Aman and Boro seasons are 2.29, 13.48 and 18.94 million tons, respectively (BBS, 2017). The climate and soil of Bangladesh are favourable for year round rice production but the yield of this crop is much below than the potential level. Agronomic management practices such as variety, spacing of planting, balanced fertilization etc. are important means. Plant spacing is an important factor, which plays a significant role on growth, development and yield if rice at its optimum level beside it, which provides scope to the plant for efficient utilization of solar radiation and nutrients (Paul et al., 2017). The growth, yield components and yield of rice are also greatly influenced by plant spacing. Under field condition farmers are using variable plant spacing 
for rice cultivation. Some of them use very closer plant spacing and others are using wider plant spacing. Closer spacing hampered intercultural operation, more competition arises among the plant for nutrient, air and light as a result plant becomes weaker and thinner consequently reduces yield (Salahuddin et al., 2009).

The importance of inorganic fertilizers in modern agriculture for increasing crop productivity needs no elaboration. The use of inorganic fertilizer has been progressively increasing and this trend is likely to continue in future to produce more agricultural products for ever increasing population. Moreover, available reports indicate that the repeated use of inorganic fertilizer alone fails to sustain desired yield, impairs the physical condition and reduce the organic matter content of soils (Ali et al., 2009; Sarkar et al., 2016). The interactive advantages of combining organic and inorganic nutrients in integrated nutrient management have proved superior to the use of each component separately in case of grain yield as well as grain protein content (Pal et al., 2016; and Biswas et al., 2016). This indicates that an integrated use of organic and inorganic fertilizers proposed to be an effective approach for sustainable crop production. The above circumstance, a research trial was conducted to evaluate effect of plant spacing and integrated nutrient management on the growth and yield of Binadhan-14.

\section{MATERIALS AND METHODS}

\section{Experimental design}

An experiment was conducted at the Agronomy Field Laboratory, Bangladesh Agricultural University, Mymensingh with a view to finding out the effect of plant spacing and integrated nutrient management on the yield of Binadhan-14. Geographically the experimental field is located at $24.75^{\circ} \mathrm{N}$ latitude and $90.50^{\circ} \mathrm{E}$ longitude at an average height of $18 \mathrm{~m}$ above the mean of sea level. The experimental site belongs to the Old Brahmaputra Floodplain (AEZ-9).

\section{Scheme of nutrient management}

The experiment consisted of three spacing viz. $25 \mathrm{~cm} \times 15 \mathrm{~cm}$, $20 \mathrm{~cm} \times 20 \mathrm{~cm}$ and $20 \mathrm{~cm} \times 15 \mathrm{~cm}$ and seven nutrient management viz., recommended dose of inorganic fertilizer @ 180-15070-65-8 kg ha-1 of Urea-TSP-MoP-Gypsum-ZnSO 4 respectively, cowdung @ $10 \mathrm{t} \mathrm{ha}^{-1}$, poultry manure @ $5 \mathrm{t} \mathrm{ha}^{-1}$, 50\% recommended inorganic fertilizer + cowdung @ $5 \mathrm{t} \mathrm{ha}^{-1}$, 50\% recommended dose of inorganic fertilizer + poultry manure @ $2.5 \mathrm{t}$ $\mathrm{ha}^{-1}, 50 \%$ recommended dose of inorganic fertilizer + cowdung @ $10 \mathrm{t} \mathrm{ha}^{-1}, 50 \%$ recommended dose of inorganic fertilizer + poultry manure @ $5 \mathrm{t} \mathrm{ha}^{-1}$. The experiment was laid out in a randomized complete block design with three replications. The land was first opened with a tractor driven plough, ploughing followed by laddering were done with a country plough and a ladder. Weeds and stubbles were removed from the field as much as possible after leveling. The lands were finally prepared and the plots were laid out on 16 July, 2014. Thirty five-day old seedlings were transplanted on 17 July, 2014 maintaining three different spacings as per experimental specification using 3-4 seedlings hill ${ }^{-1}$. Organic and inorganic fertilizers were applied according to experimental treatments. Full dose of triple super phosphate (TSP), muriate of potash (MoP), gypsum, zinc sulphate, cowdung and poultry manure were applied at the final land preparation. Nitrogen fertilizer in the form of urea was applied as per treatment of the experiment in three equal splits at 10, 30 and 45 days after transplanting (DAT).

\section{Observation and collection of data}

The crop was harvested at full maturity. The date of harvesting was confirmed when $90 \%$ of the seed became golden yellow in color. Five hills (excluding border rows and central 1 $\mathrm{m}^{2}$ area) were selected randomly from each unit plot and uprooted for recording data on yield components. After sampling a harvest area of central I $\mathrm{m} \times \mathrm{I} \mathrm{m}$ was selected from each unit plot and harvested on 12 October, 2014. The crop was threshed by pedal thrasher and the fresh weights of grain straw were recorded plot wise. The grains were cleaned and sun dried to a moisture content of $14 \%$. Finally grain and straw yields plot $^{-1}$ were recorded and converted to $\mathrm{tha}^{-1}$.

\section{Statistical analysis of data}

Data on different parameters were compiled and tabulated in proper form for statistical analysis. Analysis of variance was done with the help of computer package MSTAT. The mean differences among the treatments were tested with Duncan's Multiple Range Test (Gomez and Gomez, 1984).

\section{RESULTS AND DISCUSSION}

\section{Effect of plant spacing}

Crop characters, yield components and yield of Binadhan-14 were significantly influenced by plant spacing except plant height (Table 1). The highest number of total tillers hill ${ }^{-1}$ (8.22) was obtained at $20 \mathrm{~cm} \times 15 \mathrm{~cm}$ spacing while the lowest number of total tillers hill $^{-1}$ (7.83) were obtained at $25 \mathrm{~cm} \times 15 \mathrm{~cm}$ spacing, respectively. Variation in plant height and number of total tillers hill $^{-1}$ might be due to difference in plant spacing. This result is agreement with the findings of Salahuddin et al. (2009) and Paul et al. (2017). Effective tiller is the major factor to increase grain yield in cereal production. The highest number of effective tillers hill $^{-1}$ (6.81) and non-effective tillers hill-1 (1.40) was found at 20 $\mathrm{cm} \times 15 \mathrm{~cm}$ and $20 \mathrm{~cm} \times 20 \mathrm{~cm}$ spacing and the lowest number of effective tillers hill $^{-1}$ (6.56) was produced at $25 \mathrm{~cm} \times 15 \mathrm{~cm}$ spacing. Non-effective tillers hill $^{-1}$ was varied significantly among the spacing. This result is agreement with the findings of Salahuddin et al. (2009). The highest number grains panicle ${ }^{-1}$ (64.68) was obtained at the spacing $25 \mathrm{~cm} \times 15 \mathrm{~cm}$ which was as good (64.03) as $20 \mathrm{~cm} \times 15 \mathrm{~cm}$ spacing and the lowest number of grains panicle ${ }^{-1}$ (61.30) was produced in $20 \mathrm{~cm} \times 20 \mathrm{~cm}$ spacing (Table 1). This result is agreement with the findings of Salahuddin et al. (2009). The highest 1000 -grain weight $(22.67 \mathrm{~g})$ was found in $(20 \mathrm{~cm} \times 15 \mathrm{~cm})$ followed $20 \mathrm{~cm} \times 20 \mathrm{~cm}$ spacing and the 
lowest one $(21.10 \mathrm{~g})$ was found in $25 \mathrm{~cm} \times 15 \mathrm{~cm}$ spacing. The variation in weight of 1000 grains might be due different size of spikelets that were partly controlled by plant spacing. This result is contradictory to the result of Uddin (2003) who reported that plant spacing had no significant influence on weight of 1000 grains, because grain size was mainly controlled by gene not by environment. The highest grain yield $\left(4.78 \mathrm{t} \mathrm{ha}^{-1}\right)$ and straw yield $\left(5.38 \mathrm{t} \mathrm{ha}^{-1}\right)$ were obtained at $20 \mathrm{~cm} \times 15 \mathrm{~cm}$ followed by $20 \mathrm{~cm} \times 20 \mathrm{~cm}$ plant spacing and $25 \mathrm{~cm} \times 15 \mathrm{~cm}$ spacing produced the lowest grain (3.91 $\left.\mathrm{t} \mathrm{ha}^{-1}\right)$ and straw $\left(4.64 \mathrm{t} \mathrm{ha}^{-1}\right)$ yields. The increase in grain yield with plant spacing $20 \mathrm{~cm} \times 15 \mathrm{~cm}$ might be attributed to higher number of effective tillers hill $^{-1}$ while the highest number of total tillers hill $^{-1}$ was responsible for highest straw yield. The highest harvest index (47.07\%) was obtained at $20 \mathrm{~cm} \times 15 \mathrm{~cm}$ spacing followed by $20 \mathrm{~cm} \times 20 \mathrm{~cm}$ spacing and the lowest one (45.73\%) from $25 \mathrm{~cm} \times 15 \mathrm{~cm}$ of spacing.

Effect of integrated nutrient management

Crop characters, yield components and yield of Binadhan-14 were significantly influenced by integrated nutrient management except sterile spikelets panicle ${ }^{-1}$. The tallest plant $(82.78 \mathrm{~cm})$ was recorded in treatment $\mathrm{N}_{4}(50 \%$ recommended dose of inorganic fertilizer + cowdung @ $5 \mathrm{t} \mathrm{ha}^{-1}$ ) while the lowest plant height $(79.27 \mathrm{~cm})$ was obtained in $\mathrm{N}_{5}(50 \%$ recommended dose of inorganic fertilizer + poultry manure @ $2.5 \mathrm{t} \mathrm{ha}^{-1}$ ) (Table 2). Combined application of recommended dose of inorganic fertilizer and cowdung might enhance the growth of rice plant which eventually produced the tallest plant. Haga et al. (1989) also reported the similar phenomenon. The highest number of total tillers hill $^{-1}$ (8.25) was obtained from the treatment $\mathrm{N}_{6}(50 \%$ recommended dose of inorganic fertilizer + cowdung @10 t ha ${ }^{-1}$ ) followed by $\mathrm{N}_{4}$ (50\% recommended dose of inorganic fertilizer + cowdung @ $5 \mathrm{t} \mathrm{ha}^{-1}$ ) (8.16) the lowest number of total tillers hill ${ }^{-1}$ (7.69) was found in $\mathrm{N}_{2}$ (cowdung @ $10 \mathrm{t} \mathrm{ha}^{-1}$ ) (Table 2). Similar result was also reported by Kamal et al. (1999). The highest number of effective tillers hill $^{-1}$ (6.89) was obtained from the treatment $\mathrm{N}_{4}$ (50\% recommended dose of inorganic fertilizer + cowdung @ $5 \mathrm{t} \mathrm{ha}^{-1}$ ) followed by $\mathrm{N}_{1}$ (recommended dose of inorganic fertilizer @ 180-150-70-65-8 kg ha-1 of Urea-TSP-MoPGypsum- $\mathrm{ZnSO}_{4}$ respectively while the lowest number of effective tillers hill $^{-1}$ (6.56) was recorded in $\mathrm{N}_{5}$ (50\% recommended dose of inorganic fertilizer + poultry manure @ $\left.2.5 \mathrm{t} \mathrm{ha}^{-1}\right)$.

Table 1. Effect of plant spacing on the yield components and yield of Binadhan-14.

\begin{tabular}{|c|c|c|c|c|c|c|c|c|c|c|}
\hline Plant spacing & $\begin{array}{l}\text { Plant } \\
\text { height } \\
\text { (cm) }\end{array}$ & $\begin{array}{c}\text { Total } \\
\text { tillers } \\
\text { hill }^{-1} \\
\text { (no.) }\end{array}$ & $\begin{array}{l}\text { Effective } \\
\text { tillers } \\
\text { hill }^{-1} \text { (no.) }\end{array}$ & $\begin{array}{c}\text { Non- } \\
\text { effective } \\
\text { tillers } \\
\text { hill }^{-1} \text { (no.) }\end{array}$ & $\begin{array}{c}\text { Grains } \\
\text { panicle }^{-1} \\
\text { (no). }\end{array}$ & $\begin{array}{c}\text { Sterile } \\
\text { spikelets } \\
\text { panicle }^{-1}\end{array}$ & $\begin{array}{c}\text { 1000- } \\
\text { grains } \\
\text { weight (g) }\end{array}$ & $\begin{array}{l}\text { Grain } \\
\text { yield } \\
\left(\mathrm{t} \mathrm{ha}^{-1}\right)\end{array}$ & $\begin{array}{c}\text { Straw } \\
\text { yield } \\
\left(\mathrm{t} \mathrm{ha}^{-1}\right)\end{array}$ & $\begin{array}{c}\text { Harvest } \\
\text { index } \\
(\%)\end{array}$ \\
\hline $25 \mathrm{~cm} \times 15 \mathrm{~cm}$ & 81.10 & $7.83^{b}$ & $6.56^{b}$ & $1.28^{b}$ & $64.68^{a}$ & 25.23 & $21.10^{c}$ & $3.91^{c}$ & $4.64^{c}$ & $45.73^{b}$ \\
\hline $20 \mathrm{~cm} \times 20 \mathrm{~cm}$ & 81.56 & $7.88^{b}$ & $6.62^{b}$ & $1.40^{\mathrm{b}}$ & $61.30^{\mathrm{b}}$ & 25.53 & $21.93^{\mathrm{b}}$ & $4.37^{b}$ & $5.16^{\mathrm{b}}$ & $45.89^{b}$ \\
\hline $20 \mathrm{~cm} \times 15 \mathrm{~cm}$ & 80.67 & $8.22^{\mathrm{a}}$ & $6.81^{a}$ & $1.27^{\mathrm{a}}$ & $64.03^{a}$ & 25.56 & $22.67^{a}$ & $4.78^{a}$ & $5.38^{a}$ & $47.07^{a}$ \\
\hline$s \bar{x}$ & 0.465 & 0.084 & 0.52 & 0.034 & 0.420 & 0.234 & 0.210 & 0.024 & 0.037 & 0.314 \\
\hline $\begin{array}{l}\text { Level of } \\
\text { significance }\end{array}$ & NS & $* *$ & $* *$ & $* *$ & $* *$ & NS & $* *$ & $* *$ & ** & $* *$ \\
\hline CV (\%) & 2.63 & 4.85 & 3.54 & 12.02 & 3.04 & 4.21 & 4.21 & 2.46 & 3.35 & 3.12 \\
\hline
\end{tabular}

In a column, figures with same letter(s) or without letter do not differ significantly whereas figures with dissimilar letter differ significantly as per $\mathrm{DMRT}^{* *}=$ Significant at $1 \%$ level of probability.

Table 2. Effect of integrated nutrient management on yield components and yield of Binadhan-14.

\begin{tabular}{|c|c|c|c|c|c|c|c|c|c|c|}
\hline $\begin{array}{l}\text { Nutrient } \\
\text { management }\end{array}$ & $\begin{array}{l}\text { Plant } \\
\text { height } \\
(\mathrm{cm})\end{array}$ & $\begin{array}{c}\text { Total } \\
\text { tillers } \\
\text { hill }^{-1} \\
\text { (no.) }\end{array}$ & $\begin{array}{c}\text { Effective } \\
\text { tillers } \\
\text { hill }^{-1} \\
\text { (no.) }\end{array}$ & $\begin{array}{c}\text { Non- } \\
\text { effective } \\
\text { tillers hill } \\
{ }^{-1} \text { (no) }\end{array}$ & $\begin{array}{l}\text { Grains } \\
\text { panicle }^{-1}\end{array}$ & $\begin{array}{c}\text { Sterile } \\
\text { spikelets } \\
\text { panicle }^{-1}\end{array}$ & $\begin{array}{l}1000- \\
\text { grains } \\
\text { weight } \\
\text { (g) }\end{array}$ & $\begin{array}{l}\text { Grain } \\
\text { yield } \\
\left(\mathrm{t} \mathrm{ha}^{-1}\right)\end{array}$ & $\begin{array}{c}\text { Straw } \\
\text { yield } \\
\left(\mathrm{t} \mathrm{ha}^{-1}\right)\end{array}$ & $\begin{array}{l}\text { Harvest } \\
\text { index (\%) }\end{array}$ \\
\hline $\mathrm{N}_{1}$ & $82.44^{\mathrm{ab}}$ & $8.10^{\mathrm{abc}}$ & $6.8^{0 \mathrm{~b}}$ & $1.32^{\mathrm{ab}}$ & $64.28^{a}$ & 25.26 & $21.58^{d}$ & $4.17^{g}$ & $5.34^{g}$ & 46.68 \\
\hline $\mathrm{N}_{2}$ & $79.92^{\mathrm{cd}}$ & $7.69 a$ & $6.58^{a}$ & $1.35^{\mathrm{ab}}$ & $61.05^{a b}$ & 25.25 & $21.29^{c d}$ & $3.92^{f}$ & $4.54^{f}$ & 46.28 \\
\hline $\mathrm{N}_{3}$ & $81.02^{\mathrm{abcd}}$ & $7.96^{\mathrm{abc}}$ & $6.62^{b}$ & $1.33^{\mathrm{ab}}$ & $62.60^{\mathrm{b}}$ & 25.93 & $20.94^{\mathrm{bcd}}$ & $3.80^{\mathrm{e}}$ & $4.32^{\mathrm{e}}$ & 46.74 \\
\hline $\mathrm{N}_{4}$ & $82.78 a$ & $8.16^{\mathrm{ab}}$ & $6.89^{\mathrm{ab}}$ & $1.35^{\mathrm{ab}}$ & $64.47^{a}$ & 25.43 & $21.92^{b c}$ & $4.31^{d}$ & $5.08^{d}$ & 45.81 \\
\hline $\mathrm{N}_{5}$ & $79.27^{d}$ & $8.11^{\mathrm{ab}}$ & $6.56^{\mathrm{ab}}$ & $1.45^{\mathrm{a}}$ & $62.50^{\mathrm{ab}}$ & 26.23 & $22.21^{\mathrm{abc}}$ & $4.49^{c}$ & $4.74^{c}$ & 43.40 \\
\hline $\mathrm{N}_{6}$ & $81.88^{a b c}$ & $8.25^{c}$ & $6.79^{b}$ & $1.14^{c}$ & $64.05^{a}$ & 25.06 & $22.43^{\mathrm{ab}}$ & $4.78^{b}$ & $5.57^{\mathrm{b}}$ & 46.18 \\
\hline$N_{7}$ & $80.46^{\mathrm{bcd}}$ & $7.80^{b c}$ & $6.67^{\mathrm{b}}$ & $1.24^{b c}$ & $64.41^{a}$ & 24.91 & $22.91^{a}$ & $5.02^{a}$ & $5.84^{a}$ & 46.22 \\
\hline$s \bar{x}$ & 0.711 & 0.129 & 0.079 & 0.053 & 0.642 & 0.357 & 0.307 & 0.037 & 0.057 & 0.479 \\
\hline $\begin{array}{l}\text { Level of } \\
\text { significance }\end{array}$ & $* *$ & $*$ & * & $* *$ & $* *$ & NS & $* *$ & $* *$ & $* *$ & NS \\
\hline CV (\%) & 2.63 & 4.85 & 3.54 & 12.02 & 3.04 & 4.21 & 4.21 & 2.46 & 3.35 & 3.12 \\
\hline
\end{tabular}

In a column, figures with same letter(s) or without letter do not differ significantly whereas figures with dissimilar letter differ significantly as per DMRT $^{* *}=$ Significant at $1 \%$ level of probability; $\mathrm{N}_{1}=$ recommended dose of inorganic fertilizer @ 180-150-70-65-8 kg ha ${ }^{-1}$ of Urea-TSP-MoPGypsum-ZnSO ${ }_{4}$ respectively; $\mathrm{N}_{2}=$ Cowdung @ $10 \mathrm{t} \mathrm{ha}^{-1} ; \mathrm{N}_{3}=$ Poultry manure @ $5 \mathrm{t} \mathrm{ha}^{-1} ; \mathrm{N}_{4}=50 \%$ recommended dose of inorganic fertilizer + cowdung @ $5 \mathrm{t} \mathrm{ha}^{-1} ; \mathrm{N}_{5}=50 \%$ recommended dose of inorganic fertilizer + poultry manure @ $2.5 \mathrm{t} \mathrm{ha}^{-1} ; \mathrm{N}_{6}=50 \%$ recommended dose of inorganic fertilizer + cowdung @ $10 \mathrm{t} \mathrm{ha}^{-1} ; \mathrm{N}_{7}=50 \%$ recommended dose of inorganic fertilizer + poultry manure @ $5 \mathrm{t} \mathrm{ha}^{-1}$. 
Ahmed and Rahman (1991) differing in view that organic and inorganic fertilizers increased tiller number hill $^{-1}$. The number of non-effective tillers hill ${ }^{-1}$ ranged from 1.14 to 1.45 . The highest number of non-effective tillers hill $^{-1}$ (1.45) was recorded from $\mathrm{N}_{5}$ (50\% recommended dose of inorganic fertilizer + poultry manure @ $2.5 \mathrm{t} \mathrm{ha}^{-1}$ ) and the lowest number of non-effective tillers hill $^{-1}$ (1.14) was recorded from the fertilizer treatment $\mathrm{N}_{6}(50 \%$ recommended dose of inorganic fertilizer + cowdung @ $10 \mathrm{t} \mathrm{ha}^{-1}$ respectively) (Table $2)$. The highest number of grains panicle ${ }^{-1}$ (64.47) was obtained from treatment $\mathrm{N}_{4}(50 \%$ recommended dose of inorganic fertilizer + cowdung @ $5 \mathrm{t} \mathrm{ha}^{-1}$ ) and the lowest (61.05) number of grains panicle ${ }^{-1}$ was obtained from $\mathrm{N}_{2}$ (cowdung @ $10 \mathrm{t} \mathrm{ha}^{-1}$ ). The highest 1000 -grain weight $(22.91 \mathrm{~g})$ was produced in the treatment $\mathrm{N}_{7}$ (50\% recommended dose of inorganic fertilizer + poultry manure @ $5 \mathrm{t} \mathrm{ha}^{-1}$ ) followed by $\mathrm{N}_{6}$ (50\% recommended dose of inorganic fertilizer + cowdung @ $10 \mathrm{t} \mathrm{ha}^{-1}$ ) (22.43 g), $\mathrm{N}_{5}$ (50\% recommended dose of inorganic fertilizer + poultry manure @ $2.5 \mathrm{t} \mathrm{ha}^{-1}$ ) (22.21), N 4 (50\% recommended inorganic

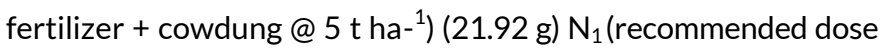
of inorganic fertilizer @ 180-150-70-65-8 kg ha-1 of Urea-TSPMoP-Gypsum-ZnSO4 respectively) (21.58), $\mathrm{N}_{2}$ (cowdung @ $10 \mathrm{t}$ $\mathrm{ha}^{-1}$ ) (21.29 g). The lowest 1000-grain weight (20.94 g) was recorded in $\mathrm{N}_{3}$ (poultry manure @ $5 \mathrm{t} \mathrm{ha}^{-1}$ ) (Table 2). The highest grain yield ( $5.02 \mathrm{t} \mathrm{ha}^{-1}$ ) was produced in $\mathrm{N}_{7}$ (50\% recommended dose of inorganic fertilizer + poultry manure @ $5 \mathrm{t} \mathrm{ha}^{-1}$ ) while the lowest grain yield $\left(3.80 \mathrm{t} \mathrm{ha}^{-1}\right)$ was recorded when fertilized with (poultry manure @ $5 \mathrm{t} \mathrm{ha}^{-1}$ ). Application of recommended dose of inorganic fertilizer and poultry manure increased grains panicle ${ }^{-1}$ and 1000 -grain weight which ultimately resulted in the increase of grain yield. This result is in conformity with the findings of Singh and Pillai (1996). The straw yields ranged from 4.32 $-5.84 \mathrm{t} \mathrm{ha}^{-1}$. The highest straw yield $\left(5.84 \mathrm{t} \mathrm{ha}^{-1}\right)$ was produced in the treatment $\mathrm{N}_{7}$ (50\% recommended dose of inorganic fertilizer + poultry manure @ $\left.5 \mathrm{t} \mathrm{ha}^{-1}\right)$ followed by $\mathrm{N}_{6}(50 \%$ recommended dose of inorganic fertilizer + cowdung @ $10 \mathrm{t} \mathrm{ha}^{-1}$ ) and the lowest straw yield ( $4.32 \mathrm{t} \mathrm{ha}^{-1}$ ) was produced in $\mathrm{N}_{3}$ (poultry manure @ $5 \mathrm{t}$ $\mathrm{ha}^{-1}$ ) (Table 2). Effect of integrated nutrient management on harvest index was not statistically significant. However, numerically the highest harvest index (46.74\%) obtained in $\mathrm{N}_{3}$ (Poultry manure @ $5 \mathrm{t} \mathrm{ha}^{-1}$ ) while the lowest one (43.40\%) was obtained in $\mathrm{N}_{5}(50 \%$ recommended dose of inorganic fertilizer + poultry manure @ 2.5 t ha $^{-1}$ ). Similar trend was reported by Ali et al. (2018) who stated that combined application of inorganic fertilizer with poultry manure increased grain and straw yields of rice.

Effect of interaction between plant spacing integrated nutrient management

Crop characters yield components and yield of Binadhan-14 were significantly influenced by interaction between plant spacing and integrated nutrient management. The tallest plant $(84.74 \mathrm{~cm})$ was recorded in $\mathrm{S}_{3} \times \mathrm{N}_{4}$ (spacing $20 \mathrm{~cm} \times 15 \mathrm{~cm}$ with $50 \%$ recommended dose of inorganic fertilizer + cowdung @ $5 \mathrm{t} \mathrm{ha}^{-1}$ while the shortest one $\left(77.67 \mathrm{~cm}\right.$ ) was found in $S_{3} \times N_{2}$ (spacing 20 $\mathrm{cm} \times 15 \mathrm{~cm}$ with cowdung @ $10 \mathrm{t} \mathrm{ha}^{-1}$ ) (Table 3). The highest number of total tillers hill ${ }^{-1}$ (8.87) was found in $S_{3} \times N_{1}$ (spacing $20 \mathrm{~cm} \times 15 \mathrm{~cm}$ with recommended dose of inorganic fertilizer @ 180-150-70-65-8 kg ha-1 of Urea-TSP-MoP-Gypsum-ZnSO 4 respectively and $\mathrm{S}_{3} \times \mathrm{N}_{4}$ (spacing $20 \mathrm{~cm} \times 15 \mathrm{~cm}$ with $50 \%$ recommended dose of inorganic fertilizer + cowdung @ $5 \mathrm{t} \mathrm{ha}^{-1}$ ) while the lowest number of total tillers hill ${ }^{-1}$ (7.20) was found in the combination $\mathrm{S}_{2} \times \mathrm{N}_{2}$ (plant spacing $20 \mathrm{~cm} \times 20 \mathrm{~cm}$ fertilized with cowdung @ $10 \mathrm{t} \mathrm{ha}^{-1}$ )(Table 3). The highest number of effective tillers hill ${ }^{-1}$ (7.4) was recorded in $\mathrm{S}_{3} \times \mathrm{N}_{1}$ (plant spacing $20 \mathrm{~cm} \times 15 \mathrm{~cm}$ fertilized with recommended dose of inorganic fertilizer @ 180-150-70-65-8 kg ha-1 of Urea-TSP-MoP-Gypsum $-\mathrm{ZnSO}_{4}$ respectively while the lowest number effective tillers hill $^{-1}$ (6.00) was found in the combination of $S_{2} \times N_{3}$ (spacing 20 $\mathrm{cm} \times 20 \mathrm{~cm}$ with poultry manure @ $\left.5 \mathrm{t} \mathrm{ha}^{-1}\right)$. The highest number of non-effective tillers hill $^{-1}(1.60)$ was found in the combination of $\mathrm{S}_{1} \times \mathrm{N}_{2}$ (spacing $25 \mathrm{~cm} \times 15 \mathrm{~cm}$ with cowdung @ $10 \mathrm{t} \mathrm{ha}^{-1}$ ) and $\mathrm{S}_{3} \times \mathrm{N}_{5}$ (spacing $20 \mathrm{~cm} \times 15 \mathrm{~cm}$ with $50 \%$ recommended dose of inorganic fertilizer + poultry manure @ $2.5 \mathrm{t} \mathrm{ha}^{-1}$ ) while the lowest one (0.87) was observed in $\mathrm{S}_{2} \times \mathrm{N}_{1}$ (spacing $20 \mathrm{~cm} \times 20 \mathrm{~cm}$ with recommended dose of inorganic fertilizer @ 180-150-70-65-8 kg ha-1 of Urea-TSP-MoPGypsum-ZnSO4 respectively) (Tab1e 3). The highest number of total grains panicle ${ }^{-1}$ (68.61) was obtained from treatment combination $\mathrm{S}_{1} \times \mathrm{N}_{7}$ (spacing $25 \mathrm{~cm} \times 15 \mathrm{~cm}$ with $50 \%$ recommended dose of inorganic fertilizer + poultry manure @ $5 \mathrm{t} \mathrm{ha}^{-1}$ ) which was as good as $\mathrm{S}_{3} \times \mathrm{N}_{6}$ (spacing $20 \mathrm{~cm} \times 15 \mathrm{~cm}$ with $50 \%$ recommended dose of inorganic fertilizer + cowdung @ $10 \mathrm{t} \mathrm{ha}^{-1}$ ) and $\mathrm{S}_{3} \times \mathrm{N}_{7}$ (spacing $20 \mathrm{~cm} \times 15 \mathrm{~cm}$ with recommended dose of inorganic fertilizer + poultry manure @ $5 \mathrm{t} \mathrm{ha}^{-1}$ ) whereas the lowest number of total grains panicle ${ }^{-1}$ (58.26) was obtained from the combination $\mathrm{S}_{1} \times \mathrm{N}_{2}$ (spacing $25 \mathrm{~cm} \times 15 \mathrm{~cm}$ with cowdung @ $10 \mathrm{t} \mathrm{ha}^{-1}$ ) (Table 3). The highest number of sterile spikelets panicle $^{-1}$ (27.14) was observed in $\mathrm{S}_{3} \times \mathrm{N}_{5}$ (spacing $20 \mathrm{~cm} \times 15 \mathrm{~cm}$ with $50 \%$ recommended inorganic fertilizer + poultry manure @ $2.5 \mathrm{t} \mathrm{ha}^{-1}$ ) and the lowest number of sterile spikelets panicle ${ }^{-1}$ (24.45) was obtained in $\mathrm{S}_{3} \times \mathrm{N}_{6}$ (spacing $20 \mathrm{~cm} \times 15 \mathrm{~cm}$ with $50 \%$ recommended dose of inorganic fertilizer + cowdung @ 10 $\mathrm{t} \mathrm{ha}^{-1}$ ). The highest 1000 -grain weight $(23.90 \mathrm{~g})$ was obtained from $\mathrm{S}_{3}$ $\times \mathrm{N}_{7}$ (spacing $20 \mathrm{~cm} \times 15 \mathrm{~cm}$ fertilized with $50 \%$ recommended dose of inorganic fertilizer + poultry manure @ $\left.5 \mathrm{t} \mathrm{ha}^{-1}\right)$ and lowest (20.00g) from the combination of $\mathrm{S}_{1} \times \mathrm{N}_{3}$ (spacing $25 \mathrm{~cm} \times 15 \mathrm{~cm}$ with poultry manure @ $\left.5 \mathrm{t} \mathrm{ha}^{-1}\right)$. The highest grain yield $\left(5.53 \mathrm{t} \mathrm{ha}^{-1}\right)$ was obtained from the interaction $\mathrm{S}_{3} \times \mathrm{N}_{7}$ (spacing $20 \mathrm{~cm} \times 15 \mathrm{~cm}$ fertilized $50 \%$ recommended dose of inorganic fertilizer + poultry manure @ $5 \mathrm{t} \mathrm{ha}^{-1}$ ) and the lowest grain yield $\left(3.50 \mathrm{t} \mathrm{ha}^{-1}\right)$ was obtained from the combination of $\mathrm{S}_{2} \times \mathrm{N}_{5}$ (spacing $20 \mathrm{~cm} \times 20$ $\mathrm{cm}$ with $50 \%$ recommended dose of inorganic fertilizer + poultry manure @ $\left.2.5 \mathrm{t} \mathrm{ha}^{-1}\right)$. The highest straw yield $\left(6.23 \mathrm{t} \mathrm{ha}^{-1}\right)$ was obtained from the interaction of $S_{3} \times N_{7}$ (spacing $20 \mathrm{~cm} \times 15 \mathrm{~cm}$ with $50 \%$ recommended dose of inorganic fertilizer + poultry manure@ $\left.5 \mathrm{t} \mathrm{ha}^{-1}\right)$ and the lowest one $\left(4.30 \mathrm{t} \mathrm{ha}^{-1}\right)$ was in the combination of $\mathrm{S}_{1} \times \mathrm{N}_{2}$ (spacing $25 \mathrm{~cm} \times 15 \mathrm{~cm}$ with cowdung @ 10 tha $^{-1}$ ) (Table 3). 
Table 3. Effect of interaction between plant spacing and integrated nutrient management on yield components and yield of Binadhan-14.

\begin{tabular}{|c|c|c|c|c|c|c|c|c|c|c|}
\hline $\begin{array}{c}\text { Interaction } \\
\text { (plant spacing } \times \\
\text { integrated } \\
\text { nutrient } \\
\text { management) }\end{array}$ & $\begin{array}{l}\text { Plant height } \\
\text { (cm) }\end{array}$ & $\begin{array}{l}\text { Total } \\
\text { tillers hill } \\
\text { (no.) }\end{array}$ & $\begin{array}{c}\text { Effective } \\
\text { tillers } \\
\text { hill }^{-1} \\
\text { (no.) }\end{array}$ & $\begin{array}{l}\text { Non- } \\
\text { effective } \\
\text { tillers } \\
\text { hill }^{-1} \\
\text { (no.) }\end{array}$ & $\begin{array}{c}\text { Grains } \\
\text { panicle }^{-1} \\
\text { (no). }\end{array}$ & $\begin{array}{l}\text { Sterile } \\
\text { spikelets } \\
\text { panicle }^{-1}\end{array}$ & $\begin{array}{c}\text { 1000- } \\
\text { grains } \\
\text { weight } \\
\text { (g) }\end{array}$ & $\begin{array}{l}\text { Grain } \\
\text { yield } \\
\left(\mathrm{t} \mathrm{ha}^{-1}\right)\end{array}$ & $\begin{array}{l}\text { Straw } \\
\text { yield } \\
\left(\mathrm{t} \mathrm{ha}^{-1}\right)\end{array}$ & $\begin{array}{c}\text { Harvest } \\
\text { index } \\
(\%)\end{array}$ \\
\hline $\mathrm{S}_{1} \times \mathrm{N}_{1}$ & $81.83 a^{\text {bcdeg }}$ & $8.67^{\text {defg }}$ & $7.07^{\mathrm{fg}}$ & $1.27^{\mathrm{bcd}}$ & $65.50^{\mathrm{abcde}}$ & $25.45^{\mathrm{abc}}$ & 20.80 & $4.53^{\circ}$ & $4.50 \mathrm{k}$ & 46.05 \\
\hline $\mathrm{S}_{1} \times \mathrm{N}_{2}$ & $79.22^{\text {defg }}$ & $7.60^{\mathrm{ab}}$ & $6.33^{\mathrm{abc}}$ & $1.60^{\mathrm{a}}$ & $58.26^{\mathrm{abcd}}$ & $25.64^{\mathrm{abc}}$ & 20.50 & $3.60^{\text {no }}$ & $4.30^{\mathrm{jk}}$ & 45.57 \\
\hline $\mathrm{S}_{1} \times \mathrm{N}_{3}$ & $80.28^{\mathrm{bcdefg}}$ & $7.47^{\mathrm{efg}}$ & $6.33^{\mathrm{fg}}$ & $1.13^{\mathrm{de}}$ & $58.70^{\mathrm{h}}$ & $24.66^{c}$ & 20.00 & $3.70^{\mathrm{mn}}$ & $4.50^{\mathrm{hij}}$ & 45.08 \\
\hline $\mathrm{S}_{1} \times \mathrm{N}_{4}$ & $81.91^{\text {abcdef }}$ & $7.93^{\mathrm{bcdeg}}$ & $6.60^{\text {def }}$ & $1.33^{\mathrm{abcd}}$ & $64.56^{\text {bcdef }}$ & $25.12^{\mathrm{abc}}$ & 21.30 & $4.00^{\mathrm{klm}}$ & $4.76^{\mathrm{fgh}}$ & 45.11 \\
\hline $\mathrm{S}_{1} \times \mathrm{N}_{5}$ & $82.86^{\text {bcdefg }}$ & $8.00^{\text {bcdef }}$ & $6.73^{\text {cdef }}$ & $1.27^{\mathrm{bcd}}$ & $64.38^{\text {bcdef }}$ & $26.49^{\mathrm{abc}}$ & 21.40 & $3.81^{\mathrm{jk}}$ & $4.65^{\mathrm{fgh}}$ & 45.66 \\
\hline $\mathrm{S}_{1} \times \mathrm{N}_{6}$ & $80.40^{\text {bcdefg }}$ & $7.27^{g}$ & $7.27^{\mathrm{fg}}$ & $1.27^{\mathrm{e}}$ & $65.30^{\mathrm{abcde}}$ & $26.3^{5 a b c}$ & 21.67 & $4.25^{\mathrm{hi}}$ & $4.86^{\mathrm{fg}}$ & 46.65 \\
\hline $\mathrm{S}_{1} \times \mathrm{N}_{7}$ & $83.76^{\mathrm{abc}}$ & $8.00^{\text {bcdef }}$ & $6.53^{\text {ef }}$ & $1.47^{\mathrm{abc}}$ & $68.61^{a}$ & $25.21^{\mathrm{abc}}$ & 22.00 & $4.53^{\mathrm{fg}}$ & $5.31^{d}$ & 46.02 \\
\hline $\mathrm{S}_{2} \times \mathrm{N}_{1}$ & $84.29^{\mathrm{ab}}$ & $8.60^{f g}$ & $6.80^{\mathrm{g}}$ & $0.870^{\mathrm{bcd}}$ & $62.61^{\text {defg }}$ & $25.06^{\mathrm{abc}}$ & 21.20 & $4.20^{\mathrm{Im}}$ & $4.78^{\mathrm{ijk}}$ & 46.79 \\
\hline $\mathrm{S}_{2} \times \mathrm{N}_{2}$ & $80.27^{\mathrm{abcd}}$ & $7.20^{\mathrm{ab}}$ & $6.33^{\mathrm{ab}}$ & $1.33^{\mathrm{abcd}}$ & $59.47^{\text {gh }}$ & $24.98^{b c}$ & 21.40 & $3.91^{\mathrm{jkl}}$ & $4.62^{\text {ghi }}$ & 45.84 \\
\hline $\mathrm{S}_{2} \times \mathrm{N}_{3}$ & $81.70^{\mathrm{ab}}$ & $7.67^{\text {bcde }}$ & $6.00^{\text {cde }}$ & $1.33^{\mathrm{abcd}}$ & $61.89^{\text {efgh }}$ & $24.57^{c}$ & 21.60 & $3.80^{\mathrm{hi}}$ & $4.32^{\mathrm{fgh}}$ & 46.77 \\
\hline $\mathrm{S}_{2} \times \mathrm{N}_{4}$ & $84.32 a^{\text {bcdeg }}$ & $8.13^{\text {cdefg }}$ & $6.47^{\text {ef }}$ & $1.20^{c d}$ & $64.19^{\text {bcdef }}$ & $24.87^{c}$ & 21.80 & $4.35^{g h}$ & $5.20^{\text {de }}$ & 45.54 \\
\hline $\mathrm{S}_{2} \times \mathrm{N}_{5}$ & $77.91^{\mathrm{efg}}$ & $7.46^{\text {bcde }}$ & $6.60^{\text {def }}$ & $1.47^{\mathrm{abc}}$ & $61.40^{\mathrm{fgh}}$ & $25.07^{\mathrm{abc}}$ & 22.30 & $3.50^{f g}$ & $5.50^{\text {cd }}$ & 45.18 \\
\hline $\mathrm{S}_{2} \times \mathrm{N}_{6}$ & $82.05 a^{\text {bcde }}$ & $8.07^{\text {efg }}$ & $6.33^{\mathrm{fg}}$ & $1.14^{\mathrm{de}}$ & $61.29^{\mathrm{fgh}}$ & $27.00^{\mathrm{ab}}$ & 22.40 & $4.80^{d}$ & $5.75^{\mathrm{bc}}$ & 45.50 \\
\hline $\mathrm{S}_{2} \times \mathrm{N}_{7}$ & $77.79^{f g}$ & $8.00^{\text {bcdef }}$ & $6.87^{\text {bcde }}$ & $1.13^{\mathrm{de}}$ & $65.72^{h}$ & $25.06^{\mathrm{abc}}$ & 22.82 & $5.00^{c}$ & $5.97^{\mathrm{ab}}$ & 45.57 \\
\hline $\mathrm{S}_{3} \times \mathrm{N}_{1}$ & $81.20^{\text {abcdefg }}$ & $8.87^{a}$ & $7.40^{\mathrm{a}}$ & $1.47^{\mathrm{abc}}$ & $64.73^{\text {bcdef }}$ & $25.24^{\mathrm{abc}}$ & 21.63 & $4.92^{\mathrm{ij}}$ & $5.75^{\text {ghij }}$ & 47.36 \\
\hline $\mathrm{S}_{3} \times \mathrm{N}_{2}$ & $77.67^{g}$ & $7.47^{\text {efg }}$ & $6.33^{\mathrm{fg}}$ & $1.13^{\mathrm{de}}$ & $62.61^{\text {cdefg }}$ & $25.16^{\mathrm{abc}}$ & 21.97 & $4.25^{\mathrm{hi}}$ & $4.70^{\mathrm{fgh}}$ & 47.49 \\
\hline $\mathrm{S}_{3} \times \mathrm{N}_{3}$ & $78.47^{\text {efg }}$ & $8.27^{\mathrm{abcd}}$ & $6.73^{\text {cdef }}$ & $1.53^{\mathrm{ab}}$ & $62.57^{\text {defg }}$ & $27.08^{\mathrm{ab}}$ & 22.33 & $4.60^{\mathrm{ef}}$ & $4.95^{\mathrm{ef}}$ & 46.80 \\
\hline $\mathrm{S}_{3} \times \mathrm{N}_{4}$ & $84.74^{a}$ & $8.87^{a}$ & $7.33^{a}$ & $1.53^{\mathrm{ab}}$ & $63.57^{\text {bcdef }}$ & $25.20^{\mathrm{abc}}$ & 22.67 & $4.75^{\mathrm{de}}$ & $5.40 \mathrm{~d}$ & 48.17 \\
\hline $\mathrm{S}_{3} \times \mathrm{N}_{5}$ & $79.62 c^{\operatorname{defg}}$ & $8.27^{\mathrm{abcd}}$ & $6.67^{\text {cdef }}$ & $1.60^{\mathrm{a}}$ & $61.53^{\mathrm{fgh}}$ & $27.14^{\mathrm{a}}$ & 22.93 & $4.10^{\text {cd }}$ & $4.55^{\mathrm{bc}}$ & 46.14 \\
\hline $\mathrm{S}_{3} \times \mathrm{N}_{6}$ & $83.18^{\mathrm{abcd}}$ & $8.40^{\mathrm{abc}}$ & $7.00^{\mathrm{abcd}}$ & $1.40^{\mathrm{abcd}}$ & $66.82^{\mathrm{ab}}$ & $24.45^{c}$ & 23.23 & $5.30^{\mathrm{b}}$ & $6.10^{\mathrm{a}}$ & 46.49 \\
\hline $\mathrm{S}_{3} \times \mathrm{N}_{7}$ & $79.82^{\text {cdefg }}$ & $7.40^{\text {efg }}$ & $6.27^{\mathrm{fg}}$ & $1.13^{\mathrm{de}}$ & $66.35^{\mathrm{abc}}$ & $24.47^{c}$ & 23.90 & $5.53^{\mathrm{a}}$ & $6.23^{\mathrm{a}}$ & 47.03 \\
\hline$S \bar{x}$ & 0.123 & 0.223 & 0.136 & 0.091 & 1.11 & 0.619 & 0.531 & 0.063 & 0.098 & 0.831 \\
\hline $\begin{array}{l}\text { Level of } \\
\text { significance }\end{array}$ & $* *$ & $* *$ & $* *$ & $* *$ & $* *$ & * & $\mathrm{NS}^{*}$ & * & $* *$ & NS \\
\hline CV (\%) & 2.63 & 4.85 & 3.54 & 12.02 & 3.04 & 4.21 & 4.21 & 2.46 & 3.35 & 3.12 \\
\hline
\end{tabular}

\section{Conclusion}

The highest number of effective tillers hill-1(6.81), 1000-grain weight $(22.67 \mathrm{~g})$ and grain yield $(4.78 \mathrm{t}$ ha-1) were recorded at $20 \mathrm{~cm} \times 15 \mathrm{~cm}$ spacing. In case of integrated nutrient management the highest number grains panicle-1 (64.47) was found with $50 \%$ recommended dose of inorganic fertilizer + cowdung $5 \mathrm{t}$ ha- 1 while 1000 - grain weight $(22.91 \mathrm{~g})$ and grain yield $(5.02 \mathrm{t}$ ha-1) were found when fertilized with $50 \%$ recommended dose of inorganic fertilizer + poultry manure @ $5 \mathrm{t}$ ha- 1 . The highest grain (5.53 t ha-1) and straw (6.23 t ha-1) yields were found at the interaction of $20 \mathrm{~cm} \times 15 \mathrm{~cm}$ spacing fertilized with $50 \%$ recommended dose of inorganic fertilizer + poultry manure @ 5 t ha-1. Therefore, Binadhan-14 can be transplanted at the $20 \mathrm{~cm}$ $\times 15 \mathrm{~cm}$ spacing fertilized with $50 \%$ recommended dose of inorganic fertilizer + poultry manure @ $5 \mathrm{t}$ ha-1 appears as the promising combination to obtain maximum grain yield in Aman season.
Open Access: This is an open access article distributed under the terms of the Creative Commons Attribution 4.0 License, which permits unrestricted use, distribution, and reproduction in any medium, provided the original author(s) if the sources are credited.

\section{REFERENCES}

Ahmed, F. and Rahman, M. (1991). Yield response of rice to fertilizers with and without manure. Proc. $11^{\text {th }}$ Ann. Bangladesh Sci. Conf. Sec. 1. Bangladesh Assoc. Advan. Sci. Dhaka. Bangladesh: 68

Ali, M.E., Islam, M.R. and Jahiruddin, M. (2009). Effect of integrated use of organic manures with inorganic fertilizers in the rice-rice cropping system and its impacton soil health. Bangladesh Journal of Agricultural Research, 34(1): 81-90.

Ali, M.I., Sarkar, M.A.R and Paul, S.K. (2018). Influence of plant nutrient management on the yield performance of transplant Aman rice (Oryza sativa L.). Archives of Agriculture and Environmental Science, 3(1): 49-53, 
https://dx.dpi.org/10.26832/24566632.2018.030106

BBS (Bangladesh Bureau of Statistics). (2017). The Yearbook of Agricultural Statistics of Bangladesh. Statistics Div., Minis. Plan. Govt. peoples Repub., Bangladesh, Dhaka.pp.19.

Biswas, T., Paul, S.K., Sarkar, M.A.R. and Sarkar, S.K. (2016). Integrated use of poultry manure with prilled urea and urea super granules for improving yield and protein content of aromatic rice (cv. BRRI dhan50). Progressive Agriculture, 27 (2): 86-93.

Gomez, K.A. and Gomez, A.A. (1984). Statistical Procedure for Agricultural Research Intl. Rice Res. Inst., John Wiley and Sons. New York, Chickester, brisbane, Toronto, Singapore. pp. 1-34.

Haga, L.G. and Dayag, A.M. (1989). Study on the use of four locally processed organic fertilizer in combination with chemical fertilizer on low land rice. Philippines: 6-7: 96.

Kamal, A.M.A., Islam, M.R. and Chowdhury, B.L.D. (1999). Growth performance protein content and nutrient uptake by modern varieties of rice under irrigated condition in Bangladesh. Thai Journal of Agricultural Science, 32(1): 105-110.

Pal, S., Paul, S.K., Sarkar, M.A.R. and Gupta, D.R. (2016).
Response on yield and protein content of fine aromatic rice varieties to integrated use of cowdung and inorganic fertilizers. Journal of Crop and Weed, 12 (1): 1-6.

Paul, S.K., Roy, B., Hasan, A.K. and Sarkar, M.A.R. (2017). Yield and yield components of short duration transplant Aus rice (cv. Parija) as influenced by plant spacing and nitrogen level. Fundamental and Applied Agriculture, 2(2): 233-236.

Salahuddin, K.M., Chowhdury, S.H., Munira, S., Islam, M.M. and Parvin, S. (2009). Response of nitrogen and plant spacing of transplanted Aman rice. Bangladesh Journal of Agricultural Research, 34(2): 279-285.

Sarkar, M.I.U., Rahman, M.M, Rahman, G.K.M.M. Naher, U.A. and Ahmed, M.N. (2016). Soil test based inorganic fertilizer and integrated plant nutrition system for rice (Oryza sativa L.) cultivation in inceptisols of Bangladesh. The Agriculturists, 14(1): 33-42.

Singh, A.S. and Pillai, N. (1996). Nitrogen fertilizer in transplant rice. International Rice Research Newsletter. 8(5): 27.

Uddin, M.H. (2003). Effect of plant spacing and nitrogen levels on yield of transplanted Aman rice cv. BR39. M.S. Thesis, Department of Agronomy. Bangladesh Agricultural University, Mymensingh. pp. 16-44. 